\title{
The Optional Protocol to the International Covenant on Economic, Social and Cultural Rights
}

\author{
Ayse Cebecioglu Haldız
}

\begin{abstract}
An Optional Protocol to the International Covenant on Economic, Social and Cultural Rights (ICESCR) was adopted by the UN General Assembly on 10 December 2008 and it came into force on 5 May 2013. The protocol gives individuals the right to raise complaints about violations of their rights which are enshrined by the covenant. Although, an optional protocol regulating the complaint procedure for its sister treaty, the International Covenant on Civil and Political Rights, was entered into force in 1976, it was postponed for ICESCR until 2013 because of the historic debate discussing whether these rights are justiciable or not. This division between the treaties left the protection of the ESCR in the background. This essay will analyse the extent to which the protocol resolved the historical concerns about the protection of economic, social and cultural rights under international human rights law.
\end{abstract}

Keywords: Protocol, Rights, Social, Cultural

\section{Introduction}

The General Assembly of United Nations adopted The Universal Declaration of Human Rights, which encapsulates both social (economic, social and cultural) and liberal (civil and political) human rights, in 1948 when the world was divided into two parts as Western and Eastern blocks as a result of the Cold War. ${ }^{1}$ After the adoption of the declaration, the drafting process started for a treaty that would provide an international legal protection for human rights. At the beginning of the drafting process, it was intended to prepare a single draft treaty protecting all basic human rights of everyone at the same level. But there were debates on the nature of the rights, their extends, the possible control mechanisms and the types of obligations and duties for states. ${ }^{2}$ Accordingly, while some supporting an integrated approach to the human rights, the majority were in favor of a distinction between the social and the liberal human rights.

According to Langford, these debates flared up with the beginning of the Cold War depending on different ideological and political ideas. In other words, division that the Cold War brought about was also reflected in the human rights area as in many parts of life. ${ }^{3}$ For instance, while the Western countries were supporting the civil and political rights, the Eastern Block gave more importance to the social and economic (ESC) rights. Accordingly, two separate covenants had been drafted to protect these rights under international human rights law; International Covenant on Economic, Social and Cultural Rights (ICESCR) and the International Covenant on Civil and Political Rights (ICCPR).

At first glance, it can be said that both blocks were the victors of this argument because both of them reached a treaty regulating the rights that they found more significant. However, there were significant differences between the two covenants as they had different natures. First of all, the obtainment of the rights for ICESCR was made subject to progressive realization while immediate realization was approved for the rights regulated by its sister treaty. Furthermore, while the ICCPR was calling states to take domestic judicial measures, the ICESCR ambiguously referred to legal and other measures. ${ }^{4}$ The differences between them were not limited to these; different monitoring mechanisms were also

1 'The Universal Declaration of Human Rights: History of the Document' (United Nations )

$<$ http://www.un.org/en/documents/udhr/history.shtml> accessed 25.01.2014

2 Marco Odello \& Francesco Seatzu, The UN Committee on Economic, Social and Cultural Rights (1st, Routledge, USA 2013$) 5$.

3 Malcolm Langford, "An Introduction to theOptional Protocol to the International Covenant on Economic Social and Cultural Rights [2009] Nordic Journal of Human Rights, vol.27, issue 1, p. 3-4.

4 ibid 4 
foreseen for two covenants and finally, while an optional protocol regulating the individual complaints for the ICCPR entered into force in 1976, a similar protocol for its sister treaty (ICESCR) had been postponed until 2013.

All these differences between the two treaties naturally led people to believe that the economic, social and cultural rights were less protected than the civil and political rights under international human rights law. It can be claimed that the famous 'three generations theory' of Karel Vasak, which actually categorizes the human righst into three groups according to their historical evolution, ${ }^{1}$ has contributed to this belief by creating an illusionary hierachy between the rights. ${ }^{2}$ However, an optional protocol regulating the complaint process was seen as a remedy to close the gap between the first two generations, civil-politic rights and social-economic rights, and entered into force on 5 May 2013.

This essay discusses how the Optional Protocol to the ICESCR helped to close the gap between the ICCPR and the ICESCR in terms of their protection under international human rights law. First of all, the debates on the nature and the content of economic, social and cultural rights will be introduced. Then, the birth process of the Optional Protocol will be presented by using the works of the Open-Ended Working Group, which was assigned to prepare the draft of the protocol. Finally, it will be discussed whether the protocol can become a remedy to eliminate the imbalance between the sister covenants in terms of equal protection of human rights.

\section{The Brief Outline Of The ICESCR}

Before examining the debates on the ESC rights, briefly looking at the ICESCR will be useful. The ICESCR was adopted on 16 December 1966 to promote better standards of life and social progress for everyone without discrimination. Since it is an international treaty, it creates legally binding obligations for state parties. The supervisory body of the covenant is the Committee on Economic, Social and Cultural Rights which was established on 29 May 1985. ${ }^{3}$ As of July 2008, 161 states are the parties to the ICESCR ${ }^{4}$ and some of the rights envisaged by the covenant are; the right to work, the right to form and join trade unions and the right to strike and the right to social security including social insurance. ${ }^{5}$

\section{The Debates On The Nature Of The Economic, Social And Cultural Rights}

The debates, which started during the drafting process of the Universal Declaration of Human Rights and led to the creation of the two distinct covenants on the protection of human rights, are mainly based on the justiciability of the ESCR. The main concerns of these debates, which are mostly emphasized by the proponents of distinction, can be summarized under three titles: the vague character of the ESCR which are limited to positive action, the institutional capabilities and the legitimacy concerns.

\section{A. Vague Character and Being Limited to Positive Action}

One of the key issues, which is frequently recurs to emphasize the differences between the CPR and the ESCR, is the vague character of the social rights which are limited to positive action. According to the proponents of the distinction, the civil and political rights have more absolute characteristics than the social rights to be enforceable and justiciable in a court. It can be claimed that the social rights are mostly uncertain, but there are also several civil and politic rights which are more vague and open-texture than the social rights. For instance, while the right to liberty has an uncertain characteristic, the right to education has a more precise frame by specifically stating that the primary education is compulsory and free. ${ }^{6}$

\footnotetext{
5'Definitions and Classifications: First,Second and Third Generations Rights' (Icelandic Human Rights Centre )

$<$ http://www.humanrights.is/en/human-rights-education-project/human-rights-concepts-ideas-and-fora/part-i-the concept-of-humanrights/definitions-and-classifications> accessed 27.01.2014.

2 'A Hierarchy Of Rights Protection' (Law Teacher 2013) <http://www.lawteacher.net/free-law-essays/administrative-law/a-hierarchy-ofrights-protection-administrative-law-essay.php> accessed 29.04.2015

3 'Background Information on the ICESCR' (ESCR-Net 'International Network for Economic, Social \& Cultural Rights' ) <http://www.escrnet.org/docs/i/425251> accessed 01.02.2014.

4 'The International Covenant on Economic, Social and Cultural Rights' (United Nations Treaty Collection

2014)<https://treaties.un.org/Pages/ViewDetails.aspx?src=TREATY\&mtdsg_no=IV-3\&chapter=4\&lang=en> accessed 01.02.2014.

5 Background Information on the ICESCR, ( n 6 ).

6 Aoife Nolan, Bruce Porter, Malcolm Langford, 'The Justiciability of the Economic, Social and Cultural Rights: An Updated Appraisal' [2007] CHRGJ Working Paper, No. 15, p. 9.
} 
In addition to being vague, the social rights are also compared with the civil and political rights in terms of state action. It is argued that the protection of civil and political rights is easier than that of the social rights because it requires negative state action while the social rights need positive state action in order to be protected. ${ }^{1}$ In other words, as Rubin stated, 'it is easier to tell governments that they shall not throw persons in jail without a fair trial than they shall guarantee even minimum but sufficient standards of living'. ${ }^{2}$ From this perspective, ESCR can not be justiciable in the courts because they are regarded as not specific legal rights but programmatic guidelines for national governmental policies where the governments have to take positive measures and actions to enforce and protect them. ${ }^{3}$ Moreover, as taking positive actions need money, poor states cannot afford to implement and protect these rights and so cannot be tried in a court in case of violation of these rights.

However, according to Karan, this approach ignores that the CPR may also require positive actions. For instance, for the implementation of the right to a fair trial (art 14 of the ICCPR), undoubtedly, the governments have to avoid unfair trial. However, in addition to this negative obligation, several positive obligations also arise, such as development of the judicial bodies or the training of the members of the judiciary. ${ }^{4}$ Another response to the arguments of the distinction supporters stems from the claim that the protection of the CPR is irrelevant without the protection of the ESCR. To exemplify this argument, it can be said that without the protection of the right to adequate food (art 11 (2) of ICESCR) or the right to health (art. 12 of ICESCR), the protection of the right to life (art. 6 of ICCPR) would be irrelevant.

\section{B. Institutional Capabilities}

The second objection to the justiciability of the ESCR is that there is not a competent forum to deal with the specific and social questions. In other words, international authorities could not have enough knowledge about the local conditions of the states. For instance, when somebody lodges a complaint about the violation of the right to education, the decision makers should have the information about the education system in that state. Relevant statistical data or the percentage of the budget, that is devoted to education should be known by them in order to decide whether the state meets its responsibility of fulfillment. So, it is claimed that, it is almost impossible for the Committee on Economic, Social and Cultural Rights to collect required data for each specific case while there are 161 states parties to the covenant. ${ }^{5}$

Nonetheless, although this is a reasonable objection, it is not well-founded because the committee can work with experts, lawyers, national courts and NGOs to collect the required data. Additionally, the state responsibility for the implementation of the human rights is not restricted to fulfillment, they also have obligations to respect and protect these rights. In other words, the implementation of human rights is not only related to using maximum resources and adopting appropriate measures, but it is also about respecting and protecting. States have to respect human rights by refraining from interfering with the enjoyment of the rights and have to prevent third-parties from interfering with the enjoyment of the rights. ${ }^{6}$ Therefore, the justiciability of the ESCR must be assessed in light of the three state obligations.

The decision of the African Commission on Human and People's Rights in Ogoni Case can be an excellent example to support this argument. In 1996, the African Commission received a complaint about the violation of several human rights of the Ogoni people in Nigeria. The complaint claimed that the government of Nigeria directly participated in irresponsible oil development practices in the Ogoni region. According to the complaint, the state oil company of Nigeria built a partnership with Shell Petroleum Development Company whose activities caused pollution and health problems in Ogoni Region. The complaint especially emphasised serious contamination of the soil, water and air; destruction of the homes; burning of the crops and killing of farm animals, which were all directly relevant to right to health, a healthy environment, housing and food. It was also argued that the Nigerian Government neither checked the activities of the petroleum company nor took measures for the security of local people. Besides, the government did not provide the people of the region with

1 Odello \& Statzu ( $\mathrm{n} 2) 6$.

2 Seymour J. Rubin, 'Economic and Social Human Rights and the New International Economic Order' [1986] American University International Law Review, vol.1, issue 1, p. 82.

3 Odello \& Statzu ( $\mathrm{n} 2$ ) 6.

4 Ulaş Karan, 'Sosyal Hakların Güçlendirimesi Açısından Bir İmkan: 'Bütüncül Yaklaşım'( An Opporunity for Strenghtening Social Rights)' [2007] Amme Idaresi Dergisi, vol. 40, issue 3, p. 38.

5 Dr. Tawhida Ahmed, ' Semminar 5 of International Human Rights Module' 2013, University of Reading.

6 'Key Concepts on ESCRs - What are the Obligations of States on Economic, Social and Cultural Rights?'(United Nations Human Rights 2012) <http://www.ohchr.org/EN//ssues/ESCR/Pages/WhataretheobligationsofStatesonESCR.aspx> accessed 29.01.2014. 
the information concerning the danger created by the petroleum company. Moreover, it was also alleged that the security forces of the government attacked, burnt and destroyed a number of Ogoni villages based on several pretexts. Finally, the government also failed to find the perpetrators of these attacks and punish them. ${ }^{1}$

The African Commission reached a decision in 2001 and found the Nigerian Government guilty of violations of economic, social and cultural rights enshrined in the African Charter. ${ }^{2}$ Briefly, the commission stated that the Nigerian Government had violated the ESCR of the Ogoni people by failing to perform its three minimum responsibilities; firstly, the government directly participated in the activities damaging the soil, air and water and so, damaging the health of the local people. ${ }^{3}$ So it failed to fulfill its obligation to respect. Secondly, the government did not protect its people from harms done by Shell Petroleum Company but instead used its security forces to facilitate the activities of the company. ${ }^{4}$ Therefore, it failed to fulfill its obligation to protect. Finally, the government neither provided any information nor permitted studies to be undertaken regarding environmental and healthier risks caused by the activities of the oil company. ${ }^{5}$ Hence, it also failed to perform its obligation to fulfill.

As seen in the Ogoni Case, the state obligation for the implementation of economic, social and cultural rights is not solely restricted to fulfillment. Indeed, in most of the cases, it encapsulates all three of them; respect, protect and fulfill. Therefore, approaching the issue only from the fulfillment argument and leaving the respect and the protect out of picture can mislead us in terms of the justiciability of the ESCR.

\section{Legitimacy Concerns}

Concerns related to the legitimacy are another important part of the justiciability debates. It is frequently argued that management of the state budget and formulation of the social and economic policies are under the responsibility of the elected representatives of the public. Therefore, a judicial review on these issues is perceived as a threat to democracy and to the separation of powers by many democratic countries. ${ }^{6}$

First of all, it is undoubtedly necessary that there is a constitutional protection for the economic and social rights in democratic countries to limit or direct the actions of the elected parts of the government and to protect the rights of minority groups. In this regard, the social rights enhance democracy, not undermine it. However, the problem here is that in contrast to the civil and political rights, a judicial decision on the social rights can have financial consequences which is administrated by the elected part of the government. So, it is claimed that this kind of decision can distort the historical roles of the executive branch and legislative power and it can also distort the traditional balance between the separate powers (the legislature, the executive and the judiciary). ${ }^{7}$

Although the separation of power is a significant objection to the justicibility of the social rights, it should be considered with the principle of the rule of law. Under the rule of law principle, the national courts must ensure that all rights have an appropriate and effective remedy and also ensure that the state's conduct is consistent with its obligation to respect these rights. ${ }^{8}$

\section{The Birth Of The Optional Protocol To The International Covenant On Economic, Social And Cultural Rights}

"An Optional Protocol is a legal instrument that supplements an international treaty. The term 'optional' signals that such instruments do not automatically bind states parties to the original treaty, but are subject to independent ratification." Under the UN human rights system there are several protocols regulating the individual complaint procedures. These protocols

\footnotetext{
1 Fons Coomans, 'The Ogoni Case before the African Commission on Human and Peoples' Rights' [2003] International and Comparative Law Quartely, vol.52, issue 03, p. 749-50.

2 Shira Stanton, 'Human Rights Abuses in Nigeria: "Ogoni 9" Trial against Shell to Begin April 27 in New York' (Centrre for Economic and Social Rights 2009) <http://cesr.org/article.php?id=340> accessed 29.01.2014.

3 The Secretary of the African Commission on Human and People's Rights, ' (Centre for Economic and Social Rights ) $<$ http://cesr.org/downloads/nigeriapetition.pdf> accessed 29.01.2014.

4 ibid.

5 ibid.

6 Langford, ( n 3 ) 13.

7 Nolan, Porter, Langford, ( n 10 ) 12.

8 CESCR General Comment No. 9, The Domestic Application of the Covenant, (Nineteenth Session, 1998), U.N. Doc. E/C.12/1998/24 (1998), para. 14).
} 
enable the individuals to bring a complaint to the treaty bodies authorised to supervise each human rights treaty. Currently, the number of human rights treaties having an optional protocol that enables the treaty body to receive complaints reached to four after the addition of the International Covenant on Economic, Social and Cultural Rights. ${ }^{1}$

The adoption of the Optional Protocol to the ICESCR was a prolonged process which has officially started in 1990 with the discussions in the Committee on Economic, Social and Cultural Rights. ${ }^{2}$ These discussions led the committee to draft an analytical paper to be present at the Vienna World Conference on Human Rights in 1993. In the conference, development of an optional protocol enabling it to hear individual complaints about the violations of the ESCR was encouraged. The Former Commission on Human Rights was also encouraged by the world conference to cooperate with the Committee to study the possibility of an optional protocol. Accordingly, the commission requested a report from the committee. ${ }^{3}$ The report was presented to the commission with a draft of the optional protocol in 1996. It strongly argued that the protocol would help to realization of the social rights and also would encourage the governments to ensure more effective remedies for these rights. ${ }^{4}$ However, the debates in the committee revealed that not all members agreed with the necessity of an optional protocol and not all proponents of the protocol agreed on the content. ${ }^{5}$ Subsequently, the commission asked the members to comment on this draft, but only a few states responded this request in the following three years of the submission. ${ }^{6}$

After 2001 the process was revived again with the appointment of an independent expert. The expert, Professor Hatem Korane, presented two reports supporting the optional protocol to the Commission on Human Rights and recommended the commission to form a working-group to focus on the optional protocol. On his recommendation, an Open-Ended Working Group (OEWG) was established in 2002 and the first meeting of the group was held in $2004{ }^{7}$ After that date, the group held four more meeting on the issues of the nature and the scope of state obligations under the ICESCR; the justiciability of the ESCR and the benefits of an optional protocol and its practicability. ${ }^{8}$ However the main moot point of all five sessions of the group was the justiciability of the ESCR.

During all these five sessions while most of the representatives from the GRULAC (Latin America and Caribbean Group) and African Countries were clearly supporting the protocol the countries such as China, Egypt, India, Japan, Poland, UK and USA did not agree with them on the justiciability issue and stated their opinions against the OP. On the other hand European Countries mostly remained reluctant by supporting the reinforcement of the ECSR but not clearly backing up the protocol. ${ }^{9}$

Despite all objections, a draft protocol was able to occur after lenghty discussions and it was unanimously adopted by the General Assembly on the symbolic date of 10 December 2008 which was the 60th anniversary of the Universal Decleration of Human Rights. ${ }^{10}$ Considering that the protocol was adopted unanimiously, the attitude of the opposite states during the sessions can be interpreted as an effort to weaken the protocol and extend the process as much as possible. Langford explained this situation by stating: "Indeed some opposing States privately conceded that they knew the protocol would eventually materialise, but the strategy was to delay the process as long as possible". ${ }^{11}$

\section{To WHAT Extent The Protocol Filled The Gap Between The ICESCR And The ICCPR}

1 The Optional Protocol to the International Covenant on Economic, Social and Cultural Rights (1st, Geneva Academy, Geneva 2013) 3 (footnotes).

2Arne Vandenbogaerde \& Wouter Vandenhole , 'The Optional Protocol to the International Covenant on Economic, Social and Cultural Rights: An Ex Ante Assessment of its Effectiveness in Light of the Drafting Process' [2010] Human Rights Law Review, vol. 5, issue 1, p. 207.

3 Claire Mahon, 'Progress at the Front: The Draft Optional Protocol to the International Covenant on Economic, Social and Cultural Rights' [2008] Human Rights Law Review, vol. 8, issue 4, p. 622.

4 Langford, (n 3 ) 6.

5 Mahon, ( n 23 ) 622.

6 Vandenbogaerde \& Vandenhole, ( $\mathrm{n} 26$ ) 208.

7 Mahon, (n 23 ) 623.

8 ibid.

9 Vandenbogaerde \& Vandenhole, ( $\mathrm{n} 22$ ) 210-11.

10ibid 216-17.

11 Langford ( n 3 ) 7. 
Different approaches to the human rights did not only resulted in two distinct covenants but also resulted in two different enforcement mechanisms for each of them. While an optional protocol embracing a compulsory periodic reporting procedure, an interstate complaint procedure, a friendly settlement procedure as well as an individual complaint procedure was granted to the ICCPR, the ICESCR was only endowed with a periodic reporting procedure until $2008 .{ }^{1}$

The periodic reporting system is the only compulsory monitoring procedure for all state parties of the ICESCR. In other words, submitting a comprehensive report, within two years of the entry into force of the ICESCR and after that every five years is the only duty of the state party. The reports are about the measures taken by the state for the enjoyment of the ESCR and about the progress made in the enjoyment of these rights. These reports are examined by the state representatives and the Committee on Economic, Social and Cultural Rights in a meeting. Finally, the CESCR gives recommendations to the state and if it is needed, can arrange financial assistance from other organizations to assist with the realisation of the rights. ${ }^{2}$ Therefore, only bequeathing the ICESCR with the periodic reporting system because of the traditional view regarding the ESCR as injusticiable left the covenant weak and vulnerable in comparison with its sibling covenant. However, the significant changes brought by the optional protocol closed the historical gap between the sisters. ${ }^{3}$

First of all, the adoption of the optional protocol has changed the traditional view and persuaded the governments that social rights are also justiciable. By breaking down the sixty-years taboo, the protocol provided a very significant improvement in the protection of the ESCR. Accordingly, the first article of the OP guaranteed a complaint procedure for individuals. ${ }^{4}$ This is the second improvement that is as important as breaking the taboo because as Kaime stated, to be effectively protected, individuals whose rights are guaranteed under the covenant must have an access to the protection mechanisms when their rights are violated or under the risk. ${ }^{5}$ In spite of the discussions in the working group on the selective approach and thanks to the last-minute attack of Pakistan and Algeria to include the right to self determination, a comprehensive approach for all the rights enunciated in the covenant adopted by the OP.

In addition to its communication procedure, the OP-ICESCR includes two other mechanisms in its scope; inquiry procedure and inter-state complaint procedure. 'The inter-state complaints procedure, regulated by article 10, is an opt-in procedure' ${ }^{6}$ which means that the two sides, the complaining and the defending state, should declare that they recognise the competence of the Committee in the case of an inter-state communication. ${ }^{7}$ Another significant improvement brought by the $\mathrm{OP}$ is the inquiry procedure which is regulated with article 11 stipulating that the CESCR may investigate a situation in a state party when it receives reliable information about a grave or systematic violation. ${ }^{8} \mathrm{It}$ is important because it gives an opportunity for the committee to unveil the state violations which are not declared on periodical reports. The inquiry procedure is an opt-in procedure as well. Besides these, for the full realization of economic, social and cultural rights the protocol regulates the interim measures under article 5 and the international assistance and cooperation under article 14. Based on article 5, the committee can request the state to take interim measures in order to prevent irreversible damage to the victim or victims of the claimed violation. ${ }^{9}$ Additionally, the protocol contributes to the realization of the ESCR by providing international assistance and cooperation. According to article 14, with the consent of the state party, the committee can transmit the issue to various UN institutions to get advice, recommendation and helps. In addition, the article includes the establishment of a trust fund to provide financial and technical assistance to the state parties. As the protocol stated, it is being implemented to contribute "to building national capacities in the area of economic, social and cultural rights in the context of the protocol". ${ }^{10}$

\section{Conclusion}

1 Thoko Kaime, 'Whose Rights are They Anyway? A Critical Analysis of the International Supervision Mechanisms for Economic, Social and Cultural Rights' (ZAMLII ) <http://www.unza.zm/zamlii/comment/zlj/v3706.html> accessed 02.02.2014.

2 Odello \& Statzu ( $n 2$ ) 25.

3 Kaime, ( $n 54$ ).

4 The Optional Protocol to the International Covenant on Economic, Social and Cultural Rights,(2008), article 1.

5 Kaime, ( $n 54$ ).

6 Langford, ( n 3 ) 27.

7The Optional Protocol to the ICESCR, article 10.

8 The Optional Protocol to the ICESCR, article 11

9 The Optional Protocol to the ICESCR, article 5.

10 The Optional Protocol to the ICESCR, article 14. 
Last February, Uruguay opened the door for the world to realize an ideal by providing the tenth ratification of the ICESCR Optional Protocol. Although the protocol was adopted on 10 September 2008, it was waiting for the ratifications of ten states to be entered into force. After the ratification of Uruguay, the protocol finally entered into force on 5 May 2013 and a dream came true after a long time.

The new enforcement mechanism brought by the optional protocol indicates a significant step in human rights protection. It can be said that for the first time since the Universal Human Rights Declaration was adopted, all the human rights become equal under international human rights law. By allowing individuals to lodge a complaint to the international community when their rights are violated, the new mechanism enabled the protection of fundamental social rights such as the right to food, the right to health and the right to work under international law.

The most important aspect that the optional protocol succeeded to bring forward was proving the full justiciability of the social rights As a result, the International Covenant on the Economic, Social and Cultural Rights and the International Covenant on the Civil and Political Rights, which has been enforced by the similar mechanisms for about forty years, are at the same level now. In other words the ICESCR caught up with his sister about forty years later.

However, the long process which started in 1990 and continued with lenghty discussions has not finished yet. In addition to Uruguay; Argentina, Spain, Equador, Mongolia, Bolivia, Bosnia-Herzogovina, Slovakia, El Salvador and Portugal have ratified the protocol. But, more states should ratify it to make the protocol reached its desired aim. As more states ratify the protocol worldwide, victim protection will become more significant and attainable on international level.

\section{References:}

[1] Ahmed T, ' Semminar 5 of International Human Rights Module' 2013, University of Reading.

[2] 'Background Information on the ICESCR' (ESCR-Net (International Network for Economic, Social \& Cultural Rights) ) <http://www.escr-net.org/docs/i/425251> accessed 01.02.2014.

[3] CESCR General Comment No. 9, The Domestic Application of the Covenant, (Nineteenth Session, 1998), U.N. Doc. E/C.12/1998/24 (1998).

[4] Coomans F, 'The Ogoni Case before the African Commission on Human and Peoples' Rights' [2003] International and Comparative Law Quartely, pp. 749-760.

[5] 'Definitions and Classifications: First,Second and Third Generations Rights' (Icelandic Human Rights Centre )

[6] <http://www.humanrights.is/the-human-rights project/humanrightscasesandmaterials/humanrightsconceptsideasandfora/theconceptsofhumanrightsanintrodu ction/definitionsandclassifications/> accessed 27.01.2014.

[7] Kaime T, 'Whose Rights are They Anyway? A Critical Analysis of the International Supervision Mechanisms for Economic, Social and Cultural Rights' (ZAMLII ) <http://www.unza.zm/zamlii/comment/zlj/v3706.html> accessed 02.02.2014

[8] Karan U, 'Sosyal Hakların Güçlendirilmesi Açısından Bir İmkan: 'Bütüncül Yaklaşım'( An Opporunity for Strenghtening Social Rights)' [2007] Amme Idaresi Dergisi, s.31-62.

[9] 'Key Concepts on ESCRs - What are the Obligations of States on Economic, Social and Cultural Rights?' (United Nations Human Rights 2012) <http://www.ohchr.org/EN/lssues/ESCR/Pages/WhataretheobligationsofStatesonESCR.aspx> accessed 29.01.2014.

[10] Langford M, 'An Introduction to the Optional Protocol to the International Covenant on Economic, Social and Cultural Rights' [2009] Nordic Journal of Human Rights, pp. 1-28.

[11] Mahon C, 'Progress at the Front: The Draft Optional Protocol to the International Covenant on Economic, Social and Cultural Rights' [2008] Human Rights Law Review, 617.

[12] Nolan A, Porter B, Langford M, 'The Justiciability of the Economic, Social and Cultural Rights: An Updated Appraisal' [2007] CHRGJ Working Paper 1.

[13] Odello M \& Seatzu F, The UN Committee on Economic, Social and Cultural Rights (1st, Routledge, USA 2013) 5.

[14] The Optional Protocol to the International Covenant on Economic, Social and Cultural Rights,(2008).

[15] Rubin S, 'Economic and Social Human Rights and the New International Economic Order' [1986] American University International Law Review, pp. 67-96. 
[16] Stanton S, 'Human Rights Abuses in Nigeria: "Ogoni 9" Trial against Shell to Begin April 27 in New York' (Centrre for Economic and Social Rights 2009) <http://cesr.org/article.php?id=340> accessed 29.01.2014.

[17] 'The International Covenant on Economic, Social and Cultural Rights' (United Nations Treaty Collection 2014) $<$ https://treaties.un.org/Pages/ViewDetails.aspx?src=TREATY\&mtdsg_no=IV-3\&chapter=4\&lang=en> accessed 01.02.2014.

[18] The Optional Protocol to the International Covenant on Economic, Social and Cultural Rights (1st, Geneva Academy, Geneva 2013) 3 (footnotes).

[19] The Secretary of the African Commission on Human and People's Rights, ' (Centre for Economic and Social Rights ) <http://cesr.org/downloads/nigeriapetition.pdf> accessed 29.01.2014.

[20] 'The Universal Declaration of Human Rights: History of the Document' (United Nations) $<$ http://www.un.org/en/documents/udhr/history.shtml> accessed 25.01.2014

[21] . Vandenbogaerde A. \& Vandenhole W , 'The Optional Protocol to the International Covenant on Economic, Social and Cultural Rights: An Ex Ante Assessment of its Effectiveness in Light of the Drafting Process' [2010] Human Rights Law Review, pp. 207- 237. 